\title{
Developing assessment model for bandel attitudes based on the teachings of Ki Hadjar Dewantara
}

\author{
${ }^{1}$ Restituta Estin Ami Wardani; ${ }^{2}$ Supriyoko; ${ }^{* 3}$ Yuli Prihatni \\ ${ }^{1}$ SMP Negeri 1 Kalasan \\ Jl. Jogja-Solo Km.14, Tirtomartani, Kalasan, Sleman, Yogyakarta 55571, Indonesia \\ ${ }^{2,3}$ Universitas Sarjanawiyata Tamansiswa \\ Tuntungan, Jl. Batikan UH III/1043, Tahunan, Umbulharjo, Yogyakarta 55167, Indonesia \\ *Corresponding Author. E-mail: yuliku7781@gmail.com \\ Submitted: 09 November 2018 | Revised: 14 November 2018 | Accepted: 22 November 2018
}

\begin{abstract}
The study was aimed at (1) identifying indicators for bandel attitudes in the teachings of Ki Hadjar Dewantara, and (2) finding out the results of the implementation of the developed bandel attitude assessment instrument. The study was developmental research in the affective domain using Mardapi's ten developmental steps. Subjects were selected by cluster random sampling of 392 junior secondary school students, 57 for the limited-scale try-out and 335 for the wider-scale try-out. The data analysis techniques included those for Aiken content validity, concurrent validity, and Cronbach Alpha reliability. Data for the instrument implementation were analyzed using descriptive statistics. Findings show that (1) there are six indicators for the bandel instrument to be developed in a self-assessment questionnaire format of 24 items consisting of 12 common statements and 12 factual statements; all items are valid and reliable; (2) Students' score in the implementation of the bandel assessment instrument is categorized into the very high level.
\end{abstract}

Keywords: affective assessment, bandel attitude, Ki Hadjar Dewantara

\section{Introduction}

The true concept of education has been proposed by Ki Hadjar Dewantara (KHD). As Indonesia's Father of Education, KHD maintains that education is an effort to advance the growth of good conducts (inner powers, characters), thinking (intellect), and also body (Dewantara, 2013, pp. 14-15). This can be understood that education is aimed at forming humans who have good conducts, think intellectually, and have a healthy body.

This concept is in conformity with the functions of national education. The national education functions to develop the ability of and form the characters and civilization of the nation in the frame of intellectualizing the life of the nation, developing the potentials of the students to become the persons who believe in and worship God the Omni-One; behave nobly; are healthy, skillful, creative, and inde- pendent; and become citizens who are democratic and responsible (Law of Republic of Indonesia No. 20 of 2003 on national education system, 2003).

These two educational concepts are too sufficient to develop excellent students. This excellence is not only reflected in the cognitive thinking abilities psychomotor skills but is also shown in the characters of the students. It is therefore important that character education is realized for the development of a great generation as it has been stated by Agboola and Tsai $(2012$, p. 163) that character education is a discipline to deliberately optimize students' ethical behaviors.

The reality shows that such education functions have not been achieved in as much as education in Indonesia places emphases on the cognitive domain. Students' learning outcomes are also dominated by cognitive aspects. Assessment in the affective aspects re- 
lated to feelings and sensibilities has not been done maximally. The learning-teaching processes, therefore, must pay more attention to affective aspects. Olatunji (2013) states that affective learning is related to the learners' attitudes, thoughts, and behaviors in the future. This learning mode is closely related to students' feelings when learning.

Galo (2014) shows the importance of the instrument in the assessment of the affective domain (Setiawan, 2017). The government has taken various steps in the efforts to develop affective evaluation. Two efforts have been revising Curriculum 2006 to become Curriculum 2013 and launching the enforcement of character education (EEC) in 2016.

Learning and evaluation processes are two essential components of the implementation of the Curriculum 2013. Quality learning is one that is able to achieve the basic competencies prescribed by the curriculum. Quality evaluation is able to measure, assess, and evaluate the achievement of the curricular basic competencies. According to Kumaidi (2017) in Setiawan (2017, p. 3), supporting quality learning needs quality assessment.

Ministry of Education and Culture of Republic of Indonesia (2016, pp. 1-2) states that the results of monitoring and evaluation of the implementation of Curriculum 2013 in 2014 found that one of the teachers' difficulties in the junior secondary level was related to evaluation. Approximately, $60 \%$ of the respondents reported that they were not able to plan, develop, administer, analyze, report, and even use well the evaluation. The main difficulties were related to formulating indicators, writing the test items, and conducting affective evaluation in various techniques.

Considering these facts, it is important that an instrument package is developed for evaluating students' attitudes. The development of the instrument is focused for the junior secondary school students in relation to 'obstinate' attitude, having strong persistence, perseverance, and unyielding to success. The problems to be addressed are: (1) what are the indicators for developing an instrument to measure obstinance? (2) what is the students' abstinence like as measured by the developed assessment model?
Assessment or evaluation, according to the Regulation of the Minister of Education and Culture of Republic of Indonesia No. 53 of 2015, is the process of gathering data/information about students' learning achievement in aspects of attitudes, knowledge, and skills. Assessment explains an individual's characteristics by accessing the individual's attitudes and mental processes that can be done by observation, interviews, rating scales, checklists, projective techniques, and tests (Aiken, 2003, p. 54).

According to the Ministry of Education, affective evaluation is done to find out the development of the spiritual and social attitudes of the learner (Ministry of Education and Culture of Republic of Indonesia, 2016). Affective evaluation is done to obtain the achievement of the students' spiritual and social values on the levels of receiving, responding, valuing, characterizing, and implementing.

Ministry of Education and Culture of Republic of Indonesia (2017, pp. 8-9) has simplified the 18 character values into five main character values as follows: (1) religiosity, (2) nationalism, (3) autonomy, (4) solidarity, and (5) integrity. Each main value is categorized into several sub-values. For example, autonomy is sub-categorized into work ethos, toughness, perseverance, professionalism, creativity, truth, and long-life education. At present, the whole autonomy sub-categories are important to be planted and enforced in order that students will have persistent struggles to attain education and reach ambitions.

Ki Hadjar Dewantara, a phenomenal avant-garde figure with his mental and intellectual sharpness, has given the quantum leap pillars of educational and cultural concepts. These intellectual investment inheritances become, among others, thoughts of national education and concepts of cultures that last the test of time (Susanto \& Retnaningsih, 2018 , p. 81). One of his inheritances is the saying 'ngandel-kendel-bandel-kandel', meaning that a free person who is struggling for independence should be ngandel (self-confident), kendel (risk-taking, brave), bandel (obstinate, not giving up when falling), and kandel (immune against negative criticisms) (Soenarno, 2012, p. 35). 
The sub-value toughness, perseverance, and hard-working in the EEC are in line with one of Ki Hadjar Dewantara's teachings, that is bandel, obstinate. Etymologically, the word bandel is originated from Javanese meaning 'strong'. In Indonesian, the word is defined as 'able to bear pain, not easily weep'. The word bandel is identical with powerful, unyielding, and resourceful. In the Great Dictionary of the Indonesian Language, the word 'tanggub' means (1) 'not easily defeated', 'dependable'; (2) 'very strong in self-position'; and (3) 'brave and bearing' (from pain, etc.) (Department of National Education, 2010, p. 1138).

Retno and Haryanto (2016, p. 27) found six indicators for being resourceful, namely (1) spirit of unyielding and not giving up, (2) serious in doing a task to achieve objectives/ ambition, (3) discipline, (4) diligent, (5) not afraid of failing, and (6) optimistic. Therefore, the attitude of being tough is realized in working hard, persevering, and not afraid of failing as expressed in the decree of the Ministry of Education and Culture (2017, p. 9) about the enforcement of the affective skills (EEC).

According to Dewantara (2013), the word bandel means being obstinate and patient. Bandel means not giving up when falling (Soenarno, 2012, p. 35). In Kamus Besar Babasa Indonesia, the word 'tahan uij' means (1) having the evidence for being strong; (2) willing to be tested (Department of National Education, 2010), while the word 'tawakal' means (1) giving in to God's wishes; and (2) fully trusting God (in suffering, etc.) (Department of $\mathrm{Na}$ tional Education, 2010, p. 1150).

Ki Hadjar Dewantara sees moral education is of utmost importance. Moral education is all the parents do to support the advancement of their child's life, in the sense of improving the growths of all potentials, mentally and physically, of their children (Soenarno, 2014, p. 15). By having good behaviors, every person will be able to stand as an independent person, who can instruct and control his self.

The development of this assessment instrument for measuring attitudes can be used by the teacher and students in the class. The teacher will be able to carry out his jobs easily and correctly. In addition, the students will be able to do self-evaluation honestly and easily.
The study is aimed at: first, obtaining accurate indicators as a basis for developing the bandel assessment model following $\mathrm{Ki}$ Hadjar Dewantara's teachings; and second, finding out the results of the implementation of the bandel attitude as measured by the developed assessment instrument.

\section{Method}

The study is developmental research, a research to develop a product and evaluate the effectiveness of the product (Sugiyono, 2010, p. 407). The model of the development is one suggested by Mardapi (2008, pp. 109120), consisting of (1) determining the instrument specification (2) writing the items, (3) determining the scale of the instrument, (4) deciding on the scoring system, (5) reviewing the instrument, (6) conducting try-outs, (7) analysing the items, (8) packaging the instrument, (9) administering the test, and (10) analyzing the results of the test.

The design for the try-out was constructed through theoretical reviews on education, the bandel obstinate attitude as one of KHD's teachings, and assessment according to the Regulation of the Minister of Education and Culture of Republic of Indonesia No. 23 of 2016. Initial observation was also done on the assessment instrument so far used by the teacher. Based on these reviews and observation, an initial instrument draft was constructed.

The initial instrument draft consisted of formulations of operational definitions, indicators, questionnaire items, and measurement scales. The initial draft was subjected to consultation with the advisors. The next step was the validation of the contents by experts and practitioners by using the Aiken approach. This was conducted by giving out the initial draft to the experts for quantitative evaluation. The aim of the validation was to know whether or not the instrument had decent validity measure so that it could be used for the next steps.

The next step was conducting a limitedscale try-out (readability) involving 57 students. The results of the limited-scale try-out, as empirical validation I, was used as a basis for the instrument revision. The revised in- 
strument was then administered to a sample of 335 students from seven junior secondary schools in the district area of Kalasan from the total of 6,200 students as empirical validation II. The sampling was cluster random sampling which was done by using the Krecjie and Morgan table as the basis.

The construct of the bandel instrument was developed from analyses of $\mathrm{Ki}$ Hadjar Dewantara's theories and subjected to the expert judgment. The data analyses technique of the content validity by the experts was that of item validity indexing suggested by Aiken (Kumaidi, 2014, p. 4; Setiawan, 2017, p. 36). Estimation for the non-test instrument was conducted using the Cronbach's Alpha formula $>0.700$ (Nunnally Jr., 1981, p. 245). Finally, the instrument was subjected to a concurrent validity analysis. The results of the test administration were analyzed descriptively using Excel and SPSS 17.0 on the computer.

\section{Findings and Discussion}

Findings

\section{Results of the Instrument Development}

\section{Initial Draft}

The bandel assessment instrument has been constructed by using relevant theories of effective assessment from Ki Hadjar Dewantara's teachings as the basis. A focus group discussion (FGD) was conducted to obtain a picture of the existing affective assessment instrument that is so far used by teachers. The results of the FGD was used in the writing of the instrument items.

Subsequently, the developmental steps for the instrument development were carried out as outlined by Mardapi (2008). Step 1 through Step 5 were carried out, started with the construction of the instrument specification up to the review of the instrument. The table of the specification was developed from the theories and concepts of the term bandel based on Ki Hadjar Dewantara's teachings. The results were subjected to the experts' judgment to produce six factors, namely: (1) hard-working (2) enthusiasm, (3) patience, (4) diligence, (5) unyielding, and (6) perseverance. These six indicators were then developed into item indicators of the bandel assessment model consisting of 12 items of statements and 12 items of facts. After being subjected to initial reviews, a revision was made generally on the sharpening of terms for the indicators, replacing inappropriate vocabulary words, and fixing ambiguous statements.

\section{Content Validity}

The item statements from the initial draft were subjected to consultation to four experts. The four experts were one of the Tamansiswa knowledge, one of educational psychology, one of educational evaluation, and one of instrument assessment for validation in terms of the match between the items and the indicators. Two practitioners were also asked to validate the first draft; these were a guidance-counseling teacher and an Indonesian teacher. The Aiken approach was used. The fit between the 24 item statements and six instrument indicators was represented by the Aiken indexes. All of the Aiken indexes are above 0.750 as seen in Table 1 .

Table 1. Aiken indexes for the fit between statement items and instrument indicators of bandel attitudes

\begin{tabular}{clll}
\hline No. & Indicator & Item & Aiken Index \\
\hline 1. & Hard-working & V1.p & 0.944 \\
& & V1.n & 0.833 \\
& & F1.p & 0.833 \\
2. & Enthusiasm & V2.n & 0.944 \\
& & V2.n & 0.833 \\
& & F2.p & 1.000 \\
& & F2.n & 0.889 \\
3. & Patience & V3.p & 1.000 \\
& & V3.n & 0.944 \\
& & F3.p & 1.000 \\
& & F3.n & 0.889 \\
4. & Diligence & V4.p & 1.000 \\
& & V4.n & 0.889 \\
& & F4.p & 1.000 \\
& & F4.n & 0.778 \\
5. & Unyielding & V5.p & 0.889 \\
& & V5.n & 0.833 \\
& & F5.p & 1.000 \\
& & F5.n & 0.778 \\
6. & Perseverance & V6.p & 0.944 \\
& & V6.n & 1.000 \\
& & F6.p & 0.778 \\
& & & 0.778 \\
\hline
\end{tabular}


From the Aiken Indexes in Table 1, it can be stated that all the items are in good category.

\section{Limited-Scale Try-out (Empirical V alidation I)}

After it was known that all the items were at the good category, the readability was conducted. The result of the limited-scale validation is also called empirical validity I. The limited-scale validation was done involving 57 students of Grades VII, VIII, and IX of junior high schools in the Kalasan district. The results of the try-out can be seen in Table 2 .

Table 2. Results of the readability test

\begin{tabular}{llcccc}
\hline \multirow{2}{*}{ No. } & \multirow{2}{*}{ Criteria } & \multicolumn{2}{c}{ Understanding } & \multicolumn{2}{c}{ Ease } \\
& & Total & $\mathbf{\%}$ & Total & \% \\
\hline 1. & Good & 45 & 78.95 & 48 & 84.21 \\
2. & Medium & 7 & 12.28 & 6 & 10.53 \\
3. & Poor & 5 & 8.77 & 3 & 5.26 \\
\multicolumn{2}{r}{ Total } & 57 & 100 & 57 & 100 \\
\hline
\end{tabular}

According to Table 2, most students, 45 students $(78.95 \%)$, are able to understand the instrument items up to above $75 \%$. The ease aspect of reading the instrument was responded by 48 students $(84.21 \%)$. This shows that the instrument is good to be used although it undergoes revision in word choice and terms as suggested by students.

Table 3. Results of revision

\begin{tabular}{|c|c|c|}
\hline $\begin{array}{l}\text { Item } \\
\text { No. }\end{array}$ & Before & After \\
\hline 2 & $\begin{array}{l}\text { Student continues to } \\
\text { practice until he can } \\
\text { really he can do the } \\
\text { test correctly. }\end{array}$ & $\begin{array}{l}\text { Student continues } \\
\text { to practice until he } \\
\text { really can do the } \\
\text { test correctly. }\end{array}$ \\
\hline 4 & $\begin{array}{l}\text { Student only studies } \\
\text { when there will be an } \\
\text { exam. }\end{array}$ & $\begin{array}{l}\text { Student will study } \\
\text { when there is an } \\
\text { exam. }\end{array}$ \\
\hline 9 & $\begin{array}{l}\text { There is a tendency } \\
\text { for students to play } \\
\text { with the cellphone } \\
\text { rather than to study. }\end{array}$ & $\begin{array}{l}\text { Students prefers } \\
\text { playing with the } \\
\text { cellphone to } \\
\text { studying. }\end{array}$ \\
\hline 16 & $\begin{array}{l}\text { I don't like to study } \\
\text { lesson material } \\
\text { which is very } \\
\text { difficult. }\end{array}$ & $\begin{array}{l}\text { I don't want to } \\
\text { study when the } \\
\text { lesson material is } \\
\text { difficult. }\end{array}$ \\
\hline 23 & $\begin{array}{l}\text { I don't want to do } \\
\text { home assignment } \\
\text { that is hard and } \\
\text { difficult. }\end{array}$ & $\begin{array}{l}\text { I only do easy } \\
\text { home assignment. }\end{array}$ \\
\hline
\end{tabular}

Finally, the setting of the instrument was conducted for the wiser-scale try-out.

\section{Wider-scale Try-out (Empirical V alidation II)}

The wider-scale try-out was conducted in seven junior secondary schools in Kalasan involving 335 students. The result is called empirical validation II. The results show that 24 items were valid, consisting of 12 common statements and 12 factual statements. For the reliability estimation, the Cronbach's alpha was used and it was found that the reliability value of the bandel instrument was 0.850 . This means that the instrument is reliable since its reliability coefficient is $>0.70$. The results of the reliability checks can be seen in Table 4 .

Table 4. Results of the estimation of the instrument reliability

\begin{tabular}{cc}
\hline Cronbach's Alpha & N of Items \\
\hline .850 & 24 \\
\hline
\end{tabular}

\section{Concurrent Validity}

Concurrent validity shows how each subject fits in groups which are conceptually different in terms of the treatment or decision that will be taken. In other words, the test of concurrent validity is to know whether or not there is consistency between attitudes and behaviors (Haryanto, 1994, p. 46). The results of the test for concurrent validity can be seen in Table 5.

Table 5. Matches between common statements and factual statements

\begin{tabular}{lccc}
\hline \multicolumn{1}{c}{ Indicator } & Item & Item No. & $\boldsymbol{r}$ \\
\hline Hard-working & 1.4 & 13.16 & $0.179^{*}$ \\
Enthusiasm & 3.10 & 15.22 & $0.124^{* *}$ \\
Patience & 7.12 & 19.24 & $0.143^{* *}$ \\
Diligence & 5.9 & 17.21 & $0.129^{*}$ \\
Unyielding & 6.8 & 18.20 & $0.360^{* *}$ \\
Perseverance & 2.11 & 14.23 & $0.578^{* *}$ \\
\hline
\end{tabular}

\section{Results of the Bandel Instrument Implementation}

Implementation of the use of the bandel assessment instrument was conducted on 335 junior high school students from different areas in the Kalasan district. Because of time limitation, and considering that Grade IX students were preparing for the practice exam, 
school exam, and national exam during AprilMay 2018, the same subjects were involved twice. This means that students who participated in empirical validation II were simultaneously subjects of the implementation phase.

In other words, the 335 students who took part in the second validation were subjected to the instrument. The results of the assessment were analyzed descriptively using the SPSS 17.0 software program on the computer. Descriptive analysis was also done to each indicator. The results are presented in Table 6.

Table 6. Results of the descriptive analyses of the assessment implementation

\begin{tabular}{|c|c|c|}
\hline \multicolumn{3}{|c|}{ Implementation } \\
\hline $\mathrm{N}$ & Valid & 335 \\
\hline Mean & & 80.5552 \\
\hline Median & & 81.0000 \\
\hline Std. Deviation & & 6.32662 \\
\hline Minimum & & 54.00 \\
\hline Maximum & & 93.00 \\
\hline
\end{tabular}

In Table 6, the mean score of the obstinate attitudes of the junior secondary school students in the district of Kalasan is 80.555. The minimum score is 54.00 and the maximum score is 93.00 . The median is 61.00 and the standard deviation is 6.327 . Intervals are plotted for ideal categories using the determined formula. Five levels are found from the calculation, which are categorized as very high $(\mathrm{VH})$, high $(\mathrm{H})$, medium $(\mathrm{M})$, low $(\mathrm{L})$, and very low $(\mathrm{VL})$. These results are represented in Table 7.

Table 7. Ideal categorization

\begin{tabular}{|c|c|c|c|}
\hline Interval & Category & $\begin{array}{l}\text { Absolute } \\
\text { Freq. }\end{array}$ & $\begin{array}{c}\text { Relative } \\
\text { Freq. }\end{array}$ \\
\hline $\begin{array}{l}78.00 \text { up } \\
\text { to } 96.00\end{array}$ & $\begin{array}{l}\text { Very High } \\
(\mathrm{VH})\end{array}$ & 230 & $68.65 \%$ \\
\hline $\begin{array}{l}66.00 \text { up } \\
\text { to } 78.00\end{array}$ & $\operatorname{High}(\mathrm{H})$ & 99 & $29.55 \%$ \\
\hline $\begin{array}{l}54.00 \text { up } \\
\text { to } 66.00\end{array}$ & Medium (M) & 6 & $1.79 \%$ \\
\hline $\begin{array}{l}42.00 \text { up } \\
\text { to } 54.00\end{array}$ & Low (L) & - & - \\
\hline $\begin{array}{l}42.00 \text { up } \\
\text { to } 24.00\end{array}$ & $\begin{array}{l}\text { Very Low } \\
\text { (VL) }\end{array}$ & - & - \\
\hline \multicolumn{2}{|c|}{ Total } & 335 & $100 \%$ \\
\hline
\end{tabular}

Table 7 shows that the highest frequency of the results of the bandel assessment is of the very $(\mathrm{VH})$ category with $68.65 \%$. Subsequently, the high $(\mathrm{H})$ category has $55 \%$ and medium (M) $1.79 \%$. No student has the bandel competencies at the low (L) and very low (VL) categories. These results are clearly presented in the format of a diagram in Figure 1.

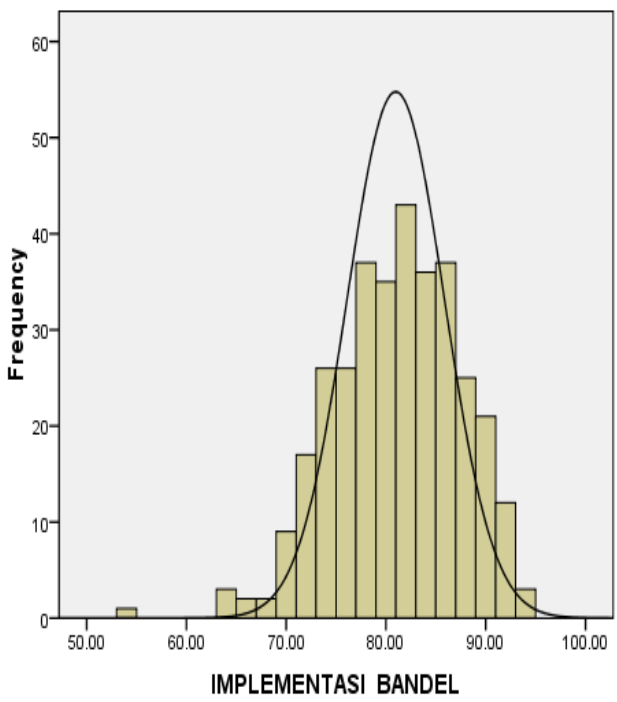

Figure 1. Results of the descriptive analyses of the implementation of the bandel assessment 


\section{Discussion}

The development of the assessment instrument for the students' bandel attitudes is based on the teachings of Ki Hadjar Dewantara. From the theoretical conceptual reviews, six indicators are found for the bandel attitudes; namely hard-working, enthusiasm, patience, diligence, unyielding, and perseverance. These six indicators are developed into the specification table of the model assessment. Self-assessment statements are written out of the specification table to be responded honestly by the students.

The resulting assessment model is a questionnaire with 24 items in the forms of 12 common statements (attitudes) and 12 factual statements (behaviors), each consisting of six positive statements and six negative statements. A modified Likert scale is used with response options scored from 1 to 4 .

The assessment of the bandel attitudes has an expressive function. This means that the common items have a correlation with the factual items, all reflect the attitudes and behaviors of the subject students on bandel characteristics.

The first draft of the instrument is subjected to consultations to education experts and Tamansiswa experts. Inputs and suggestions from the experts are used to revise the draft. The result is the construction of an initial instrument assessment for the bandel indicators.

The initial items are then subjected to expert judgment for content validity to four experts in educational evaluation and educational psychology and two practitioners (one guidance-counseling teacher and one Indonesian teacher). The results show that all items are at the good category, meaning that are in fit with the indicators, each with an Aiken index of $>0.750$. Nevertheless, minor revisions are made on some of the statements as suggested by the experts and practitioners.

The instrument having been revised, the try-outs are conducted. The first is a limited-scale try-out (readability cheeks) to 57 grades VII, VIII, and IX students of junior high schools in the Kalasan district taken by random sampling. This is empirical validation
I focusing on readability with two aspects of understanding and ease. The understanding check is to see how far the statements are understood by students, e.g. whether or not they are ambiguous in meaning. Meanwhile, the ease aspect is to see how far the vocabulary words are known and understood by students.

The results show that, out of the 57 students, $45(78.95 \%)$ are able to understand the items more than $75 \%$. The ease aspect is responded by 48 students $(84.21 \%)$. These results show that the instrument can be understood by the students so that it is feasible to be used for the wider-scale try-out. A minor revision was done, however, in word choices and terms, in accordance with students' feedbacks.

The wider-scale try-out is conducted to 335 students of grades VII, VIII, and IX of the junior secondary schools in the Kalasan district. To the results of this wider try-out, item validity, and reliability are computed. The results of the validity test show that 24 items are valid, consisting of 12 common items and 12 factual items. It can be stated that all the items are valid. They are then subjected to the reliability test. The reliability check produces the score of 0.850 to mean that the instrument is reliable.

The next step is to conduct content validation to see whether or not the instrument items represent the instrument indicators being measured. It is found that all the items do represent the indicators. Subsequently, a concurrent validity check is conducted to see that there is consistency between the attitudes and the behaviors. The results show that there is a correlation in the scores between the common statements and the factual statements, indicating that there is consistency between the attitudes and behaviors.

All validation tests have been done and the results show that the bandel assessment instrument is valid and reliable. The instrument has fulfilled the requirements of being a standardized instrument. The last step is done in the form of setting the instrument to become the final version of the instrument, ready to be administered.

The implementation of the bandel measurement using the developed product gives 
the following results. The mean score is 80.555 which is above 78.00 . This can be interpreted that the students' score of the bandel attitudes in the academic year of $2017 / 2018$ is in the very high category (VH). The same result is found for the six bandel indicators, namely hard-working, enthusiasm, patience, diligence, unyielding, and perseverance, also giving scores of the very high category.

\section{Conclusion and Suggestions}

\section{Conclusion}

Based on the concept of bandel attitude in the teachings of Ki Hadjar Dewantara, six indicators can be identified to develop the bandel assessment instrument; they are hardworking, enthusiasm, patience, diligence, unyielding, and perseverance. The instrument is developed in the format of a self-assessment questionnaire consisting of 24 statement items (12 common statements and 12 factual statement).

The findings show that the developed instrument is good. Also, the concurrent validation shows that there is consistency between students' attitudes and behaviors. A standardized instrument has been developed to measure the bandel attitudes of junior secondary school students which has the characteristics of the very good category.

\section{Suggestions}

It can be suggested to the related parties, especially junior secondary school teachers, to make use of this developed instrument to assess their students' levels of bandel attitudes. It is also suggested that teachers understand, have high enthusiasm, and work hard to develop an evaluation instrument for the affective domain so that evaluation results can be obtained for future classroom purposes. As a result, teachers will be able to do their jobs professionally, in accord with the demands of the curriculum and 21st-century educational challenges.

For educational experts and researchers, the results of this study can be used as reference material for producing assessment instruments for other components of the affective domain, especially the five indicators
(EEC) prescribed by the Ministry of Education and other noble values in the teaching of Ki Hadjar Dewantara.

\section{References}

Agboola, A., \& Tsai, K. C. (2012). Bring character education into classroom. European Journal of Educational Research, 1(2), 163-170.

Aiken, L. R. (2003). Psychological testing and assessment (11th ed.). Boston, MA: Allyn and Bacon.

Department of National Education. (2010). The Great Dictionary of the Indonesian Language (Kamus Besar Bahasa Indonesia). Jakarta: Language Center, Department of National Education.

Dewantara, K. H. (2013). Pemikiran, konsepsi, keteladanan, sikap merdeka I (Pendidikan). Yogyakarta: UST Press \& Majelis Luhur Persatuan Tamansiswa.

Haryanto, S. (1994). Pengantar teori pengukuran kepribadian. Surakarta: Sebelas Maret University Press.

Kumaidi. (2014). Validitas dan pemvalidasian instrumen penilaian karakter. In Seminar Psikometri Fakultas Psikologi Universitas Mubammadiyah Surakarta. Surakarta: Universitas Muhammadiyah Surakarta.

Law of Republic of Indonesia No. 20 of 2003 on National Education System (2003).

Mardapi, D. (2008). Teknik penyusunan instrumen tes dan nontes. Yogyakarta: Mitra Cendekia.

Ministry of Education and Culture. (2016). Modul pengembangan instrumen penilaian oleh pendidikan sekolah menengah pertama. Jakarta: Ministry of Education and Culture of Republic of Indonesia.

Ministry of Education and Culture. (2017). Konsep dan pedoman penguatan pendidikan karakter. Jakarta: Ministry of Education and Culture of Republic of Indonesia.

Nunnally Jr., J. C. (1981). Introduction to psychological measurement. New York, NY: McGraw-Hill. 
Olatunji, M. O. (2013). Teaching and assessing of affective characteristics: A critical missing link in online education. International Journal on New Trends in Education and Their Implications, 4(1), 96107.

Regulation of the Minister of Education and Culture of Republic of Indonesia No. 23 of 2016 on Educational Assessment Standard (2016).

Regulation of the Minister of Education and Culture of Republic of Indonesia No. 53 of 2015 on Learning Outcome Assessment by Educators and educator Units on Primary and Secondary Educational Levels (2015).

Retno, A., \& Haryanto, S. (2016). Pengembangan instrumen pengukuran nilai ulet peserta didik SMA di SMA Negeri 1 Buluspesantren. Wiyata Dharma: Jurnal Penelitian Dan Evaluasi Pendidikan, 4(3).

Setiawan, A. (2017). Pengembangan instrumen penilaian sikap sosial siswa pada pembelajaran tematik sekolah dasar. Thesis. Universitas Negeri Yogyakarta, Yogyakarta.
Soenarno, H. (2012). Ketamansiswaan 1: Riwayat bidup, perjuangan, dan konsepsi. Yogyakarta: Majelis Luhur Persatuan Tamansiswa.

Soenarno, H. (2014). Ketamansiswaan 3: Pendidikan di Tamansiswa. Yogyakarta: Majelis Luhur Persatuan Tamansiswa.

Sugiyono. (2010). Metode penelitian kuantitatif, kualitatif, dan $\mathrm{R}$ \& $D$. Bandung: Alfabeta.

Susanto, M. R., \& Retnaningsih, R. (2018). Melacak pemikiran avant garde Ki Hadjar Dewantara melalui konsep pendidikan nasional sebagai fenomena quantum leap dalam perspektif filsafat organisme. In Prosiding Seminar Nasional Pendidikan (Vol. 1). Yogyakarta: Direktorat Pascasarjana Pendidikan Universitas Sarjanawiyata Tamansiswa. 